\title{
Acetylcholinesterase inhibitory activities and LC-MS analysis of the antioxidant Ferula caspica M. Bieb. and F. halophila Peşmen extracts
}

\author{
Çiğdem KAHRAMAN 1 * (D) , İpek BAYSAL 2 (D) , İ. İrem ÇANKAYA ${ }^{3}$ (D) , Fatih GÖGER 4,5,6 D , \\ Neşe KIRIMER ${ }^{\circ}$ (D) , Zeliha Ş. AKDEMİR 1 (D)
}

1 Department of Pharmacognosy, Faculty of Pharmacy, Hacettepe University, 06100 Ankara, Turkey.

2 Department of Biochemistry, Faculty of Pharmacy, Hacettepe University, 06100 Ankara, Turkey.

3 Department of Pharmaceutical Botany, Faculty of Pharmacy, Hacettepe University, 06100 Ankara, Turkey.

4 Department of Pharmacy, Program in Pharmacy Services, Yunus Emre Vocational School, 26470 Eskişehir, Turkey.

5 Anadolu University Medicinal plants, Drugs and Scientific Research Centre (AUBIBAM), 26470 Eskişehir, Turkey.

6 Department of Pharmacognosy, Faculty of Pharmacy, Anadolu University, 26470 Eskişehir, Turkey.

* Corresponding Author. E-mail: cigdemm@hacettepe.edu.tr (Ç.K.); Tel. +90-544-622 7727.

Received: 27 September 2018 / Revised: 21 December 2018/ Accepted: 22 December 2018

ABSTRACT: The aim of the current study is to evaluate the biological activity of F. caspica M. Bieb. which is used for the treatment of diabetes in traditional Turkish medicine and to compare with F. halophila Peşmen. Antioxidant capacities and total phenolic contents of the plants' extracts were tested by DPPH radical scavenging assay and Folin Ciocalteu assay, respectively. Acetylcholinesterase inhibitory activities of the extracts were investigated with the aim of indicating whether there was a correlation with their antioxidant capacities. Different quinic acid and flavonoid derivatives which may be responsible for the activities of the extracts were detected using LC-MS screening in the methanol extracts. The methanol extract from the aerial parts of $F$. caspica was found to show most antioxidant capacity and acetylcholinesterase inhibitory activity.

KEYWORDS: Ferula; antioxidant capacity; acetylcholinesterase inhibition; LC-MS.

\section{INTRODUCTION}

The genus Ferula L. is the third largest genus of Apiaceae [1] represented by 23 species, 13 of which are endemic to Turkish Flora [1-8]. Ferula species are wealthy natural biological sources for developing new drug design due to traditional usage for treatment of several disorders in Anatolia as well as around the world. Some species are used as aphrodisiac, antidiabetic and anticholesterolemic agent in Turkey [9]. Besides that, antispasmodic [10, 11], antidiabetic and antihyperlipidemic [12, 13], cytotoxic [14, 15] and antimicrobial [16] activities of different Ferula species were reported previously. The aerial parts of F. caspica M. Bieb. is also traditionally used as antidiabetic in the East Anatolian region of Turkey [9].

Free radicals are products with high reactivity containing unpaired electrons such as hydroxyl radical $(\cdot \mathrm{OH})$, superoxide anion $\left(\mathrm{O}_{2}{ }^{*}\right)$ and nitric oxide $\left(\mathrm{NO}{ }^{*}\right)$ or non-radical reactive molecules derived from free radicals such as peroxynitrite (ONOO-) and hydrogen peroxide $\left(\mathrm{H}_{2} \mathrm{O}_{2}\right)$. Though these reactive oxygen species are produced by natural biochemical processes or external effects, oxidative stress damaging the biological molecules such as lipids, proteins, polysaccharides, and DNA occurs when the balance between free radicals production and antioxidant defense mechanisms deteriorates [17-19]. Such imbalance has an effect on the pathogenesis of Alzheimer's disease (AD), Parkinson's disease (PD) and other neurodegenerative diseases [20, 21]. Among them, $\mathrm{AD}$ identified by the abnormal deposition of amyloid $\beta(\mathrm{A} \beta$ ) peptide, and intracellular accumulation of neurofibrillary tangles is a common, progressive and neurodegenerative disease characterized by loss of memory and other cognitive functions [22, 23]. Plasma antioxidant levels were found to be significantly lower in AD patients [24, 25].

How to cite this article: Kahraman Ç, Baysal I, Çankaya ii, Göger F, Kırımer N, Akdemir ZŞ. Acetylcholinesterase inhibitory activities and LC-MS analysis of the antioxidant Ferula caspica M. Bieb. and F. halophila Peşmen extracts. J Res Pharm. 2019; 23(3): 543-551. 
The aim of the present work to determine the antioxidant capacities and phenolic compound profiles by LC-MS as well as the relationship between acetylcholinesterase ( $\mathrm{AChE}$ ) inhibitory and antioxidant activities of the extracts from F. caspica and F. halophila.

\section{RESULTS}

\subsection{DPPH radical scavenging capacity assay}

DPPH radical scavenging capacity assay is one the most practical, rapid and common method used for determined the antioxidant activity. In this electron transfer based assay [26], the reduction of 2,2-diphenyl-1picrylhydrazyl ( $\left.\mathrm{DPPH}^{\bullet}\right)$ by an hydrogen-donating antioxidant is identified by measuring the decrease of absorbance $\left(\mathrm{DPPH}^{\bullet}+\mathrm{A}-\mathrm{H} \rightarrow \mathrm{DPPH}-\mathrm{H}+\mathrm{A}^{\bullet}\right)$. Composing reduced $\mathrm{DPPH}-\mathrm{H}$ by transferring the proton to $\mathrm{DPPH} \cdot$ from antioxidant $(\mathrm{A}-\mathrm{H})$ results in the decolorization of the radical [27].

The methanol extracts of $F$. caspica and F. halophila showed higher antioxidant capacities compared to other extracts in DPPH radical scavenging assay (Table 1).

Table 1. DPPH radical scavenging capacity of F. caspica and F. halophila extracts.

\begin{tabular}{|c|c|c|c|c|}
\hline \multirow[t]{2}{*}{ Extracts } & \multicolumn{4}{|c|}{ \% Inhibition } \\
\hline & $25 \mu \mathrm{g} / \mathrm{ml}$ & $50 \mu \mathrm{g} / \mathrm{ml}$ & $100 \mu \mathrm{g} / \mathrm{ml}$ & $200 \mu \mathrm{g} / \mathrm{ml}$ \\
\hline $\mathrm{FC} / \mathrm{AP} / \mathrm{CHCl}_{3}$ & $11.62 \pm 0.56$ & $14.27 \pm 0.64$ & $17.35 \pm 0.73$ & $28.16 \pm 1.32$ \\
\hline $\mathrm{FC} / \mathrm{AP} / \mathrm{MeOH}$ & $10.04 \pm 0.95$ & $16.26 \pm 0.52$ & $27.16 \pm 0.67$ & $52.21 \pm 0.55$ \\
\hline FC/Root/PE & $3.53 \pm 0.32$ & $6.62 \pm 0.20$ & $8.02 \pm 0.36$ & $13.26 \pm 0.68$ \\
\hline $\mathrm{FC} /$ Root $/ \mathrm{CHCl}_{3}$ & $6.19 \pm 0.71$ & $12.33 \pm 0.87$ & $19.14 \pm 0.11$ & $31.19 \pm 0.68$ \\
\hline FC/Root/MeOH & $4.70 \pm 0.56$ & $9.90 \pm 0.75$ & $14.93 \pm 1.22$ & $28.04 \pm 0.74$ \\
\hline $\mathrm{FH} / \mathrm{AP} / \mathrm{PE}$ & - & - & $4.41 \pm 0.22$ & $6.56 \pm 0.26$ \\
\hline $\mathrm{FH} / \mathrm{AP} / \mathrm{CHCl}_{3}$ & - & $6.88 \pm 1.74$ & $9.11 \pm 2.96$ & $12.16 \pm 2.43$ \\
\hline $\mathrm{FH} / \mathrm{AP} / \mathrm{MeOH}$ & $7.30 \pm 0.08$ & $16.21 \pm 0.42$ & $28.48 \pm 0.72$ & $53.17 \pm 6.71$ \\
\hline FH/Root/PE & - & - & - & - \\
\hline $\mathrm{FH} / \mathrm{Root} / \mathrm{CHCl}_{3}$ & $3.87 \pm 2.43$ & $6.36 \pm 1.52$ & $6.17 \pm 1.39$ & $7.32 \pm 1.12$ \\
\hline FH/Root/MeOH & - & $4.46 \pm 0.43$ & $13.78 \pm 1.52$ & $21.21 \pm 0.52$ \\
\hline Quercetin & $70.21 \pm 1.42$ & $90.65 \pm 0.08$ & $90.84 \pm 0.88$ & $92.01 \pm 0.33$ \\
\hline
\end{tabular}

FC: F. caspica, FH: F. halophila, AP: Aerial parts, $\mathrm{CHCl}_{3}$ : Chloroform extract, PE: Petroleum ether extract, $\mathrm{MeOH}$ : Methanol extract.

\subsection{Determination of total phenolic content}

The basis of the method is that the spectrophotometric measurement of blue color produced by reduction of the molybdenum center in the Folin-Ciocalteu reagent while the electron donating phenolic compound is oxidized [28]: $\mathrm{Mo}(\mathrm{VI})+\mathrm{e} \rightarrow \mathrm{Mo}(\mathrm{V})$

Since the FC reagent is nonspecific to the phenolic compounds, the basic conditions with sodium carbonate are provided to allow the phenolic compounds to react [26]. The results showed that the methanol extract contains the higher phenolics with the value of $59.16 \pm 3.42 \mathrm{mg}$ gallic acid equivalent/g extract in comparison with chloroform extract (46.51 $\pm 2.03 \mathrm{mg}$ GA equivalent/g extract) (Table 2).

\subsection{Aluminium chloride colorimetric assay (Total Flavonoid Assay)}

The spectrophotometric measurement of the intensity of the chelates composed between $\mathrm{AlCl}_{3}$ and C4 keto group and the C-3 or C-5 hydroxyl groups or ortho hydroxyl groups in the A- or B-ring of the flavonoids is the principle of the assay. The results are given in Table 2. 
Table 2. Total phenolic and flavonoid contents of F. caspica and F. halophila extracts.

\begin{tabular}{lcc}
\hline \multicolumn{1}{c}{ Extracts } & $\begin{array}{c}\text { Total Phenol } \\
\text { mg GA/g extract }\end{array}$ & $\begin{array}{c}\text { Total Flavonoid } \\
\text { mg Quercetin/ g extract }\end{array}$ \\
\hline $\mathrm{FC} / \mathrm{AP} / \mathrm{CHCl}_{3}$ & $46.51 \pm 2.03$ & $8.17 \pm 0.34$ \\
$\mathrm{FC} / \mathrm{AP} / \mathrm{MeOH}$ & $59.16 \pm 3.42$ & $12.14 \pm 1.67$ \\
$\mathrm{FC} / \mathrm{Root} / \mathrm{PE}$ & $42.62 \pm 1.85$ & - \\
$\mathrm{FC} / \mathrm{Root} / \mathrm{CHCl}{ }_{3}$ & $90.33 \pm 2.94$ & - \\
$\mathrm{FC} / \mathrm{Root} / \mathrm{MeOH}$ & $36.94 \pm 2.36$ & - \\
$\mathrm{FH} / \mathrm{AP} / \mathrm{PE}$ & $21.38 \pm 2.03$ & $6.98 \pm 1.20$ \\
$\mathrm{FH} / \mathrm{AP} / \mathrm{CHCl} 3$ & $44.84 \pm 2.53$ & $33.88 \pm 3.44$ \\
$\mathrm{FH} / \mathrm{AP} / \mathrm{MeOH}$ & $67.37 \pm 3.16$ & - \\
$\mathrm{FH} / \mathrm{Root} / \mathrm{PE}$ & $8.05 \pm 1.07$ & - \\
$\mathrm{FH} / \mathrm{Root} / \mathrm{CHCl}$ & $14.53 \pm 1.18$ & - \\
$\mathrm{FH} / \mathrm{Root} / \mathrm{MeOH}$ & $18.11 \pm 1.11$ & - \\
\hline
\end{tabular}

\subsection{LC-MS analysis of phenolic compounds}

Especially, sesquiterpene and coumarin derivatives were isolated from apolar extracts of Ferula species [29-32]. Studies on the polar metabolites are unfortunately limited. The present research focused on the extracts showing antioxidant properties and is important for the preliminary screening of polar metabolites (Table 3) which can be responsible for the activity. 5-Caffeoylquinic acid was found to be the major compound in F. caspica and F. halophila aerial part extracts as shown in Figures 1-3.

Table 3. Monitored compounds in methanol extracts by LC-MS.

\begin{tabular}{|c|c|c|c|c|c|}
\hline $\begin{array}{l}\text { Rt } \\
\min \end{array}$ & $\begin{array}{l}{[\mathrm{M}-\mathrm{H}]^{-}} \\
m / z\end{array}$ & Fragment & Compounds & Extracts & Ref \\
\hline 8.9 & 353 & $191,179,135$ & 3-Caffeoylquinic acid & FC/AP, FH/AP- Root & {$[46]$} \\
\hline 10.2 & 353 & $191,179,173,135$ & 5-Caffeoylquinic acid & FC/AP-Root, FH/AP-Root & [46] \\
\hline 11.2 & 515 & $335,191,179,161,135$ & 1,3-Dicaffeoylquinic acid & FH/Root & {$[46]$} \\
\hline 12.7 & 367 & 191,173 & 5-Feruloylquinic acid & FC/AP-Root, & {$[46]$} \\
\hline 13.6 & 463 & $301,271,255,179,151$ & Quercetin-3-O- $\beta$-glucoside & $\mathrm{FC} / \mathrm{AP}, \mathrm{FH} / \mathrm{AP}$ & [47] \\
\hline 14.5 & 515 & $\begin{array}{l}353,335,191,179,173,161, \\
135\end{array}$ & 3,4/4-5-Dicaffeoylquinic acid & $\mathrm{FC} / \mathrm{AP}$ & {$[46]$} \\
\hline 14.7 & 153 & 109 & Dihydroxy benzoic acid & FC/AP-Root, & [43] \\
\hline 14.8 & 447 & $285,255,227$ & Kaempferol-3-O- $\beta$-glucoside & $\mathrm{FC} / \mathrm{AP}, \mathrm{FH} / \mathrm{AP}$ & {$[48]$} \\
\hline 15.2 & 353 & $191,179,173,135$ & Caffeoylquinic acid deriv. & $\mathrm{FH} / \mathrm{AP}$ & {$[46]$} \\
\hline 15.4 & 515 & $353,191,179$ & 1,5-Dicaffeoylquinic acid & FC/Root, FH/Root & [46] \\
\hline 15.9 & 515 & $353,191,179,173$ & 3,4/4-5-Dicaffeoylquinic acid & FC/AP-Root FH/AP & {$[46]$} \\
\hline 17.1 & 431 & $285,255,227$ & Kaempferol-3-O-a-rhamnozide & $\mathrm{FC} / \mathrm{AP}, \mathrm{FH} / \mathrm{AP}$ & {$[45]$} \\
\hline 18.2 & 529 & 367 & $\begin{array}{l}\text { Caffeoylferuloylquinic acid } \\
\text { deriv. }\end{array}$ & $\mathrm{FH} / \mathrm{AP}$ & [46] \\
\hline 19.5 & 193 & $179,161,133$ & $\begin{array}{l}\text { Dihydroxycinnamic methyl } \\
\text { ester deriv. }\end{array}$ & $\mathrm{FH} / \mathrm{AP}$ & [44] \\
\hline 21.2 & 301 & 179,151 & Quercetin/Hesperidin & $\mathrm{FH} / \mathrm{AP}$ & [49] \\
\hline
\end{tabular}




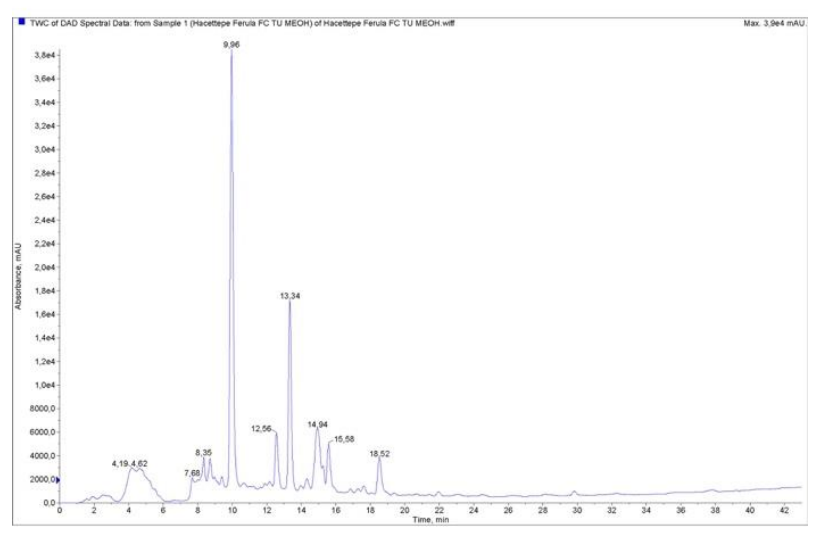

Figure 1. HPLC-DAD chromatogram of methanolic extract from the aerial parts of F. caspica

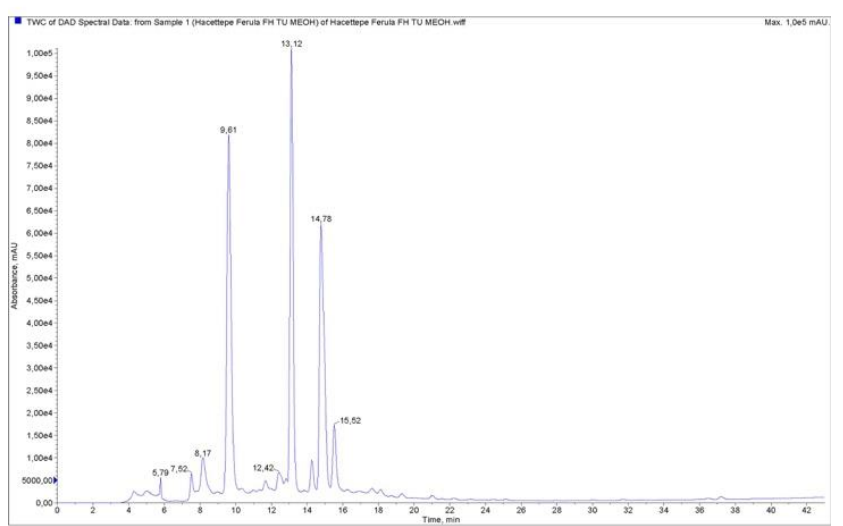

Figure 2. HPLC-DAD chromatogram of methanolic extract from the aerial parts of F. halophila

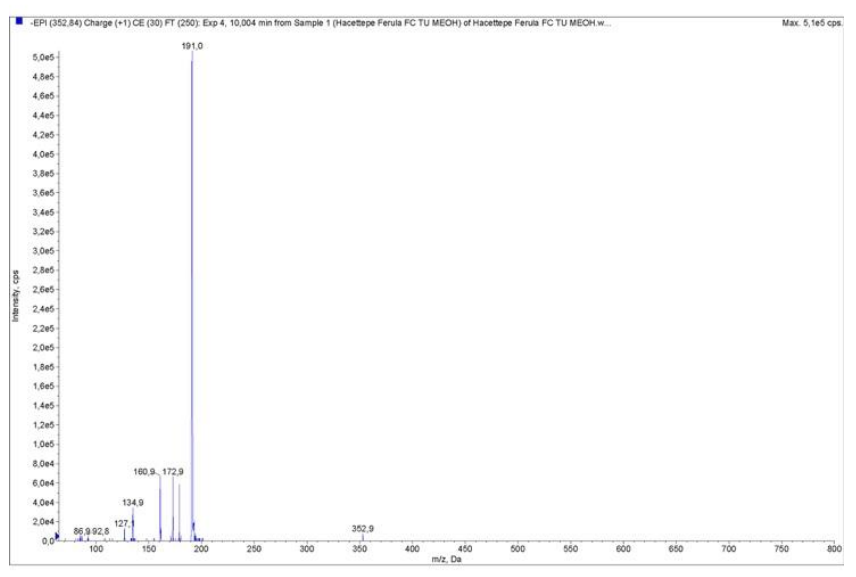

Figure 3. Mass spectrum of 5-caffeoylquinic acid.

\subsection{Acetylcholinesterase inhibitory activity}

Acetylthiocholine forms thiocholine (as well as acetate) in the presence of acetylcholinesterase enzyme, gives yellow color with dithiobisnitrobenzoic acid. Enzyme inhibition is based on the reduction of yellow color and the measurement of color intensity spectrophotometrically [33]. As enzyme inhibition results in an increasing cholinergic function, $\mathrm{AChE}$ inhibitors featured in the symptomatic treatment of Alzheimer Disease. Methanolic extract from the aerial parts of $F$. caspica demonstrated higher activity in comparison with donepezil as the standard (Table 4).

Table 4. Acetylcholinesterase inhibitory activities of the $F$. caspica and $F$. halophila extracts.

\begin{tabular}{llll}
\hline Extracts & $\mathrm{IC}_{50}(\mu \mathrm{g} / \mathrm{ml})$ & Extracts & $\mathrm{IC}_{50}(\mu \mathrm{g} / \mathrm{ml})$ \\
\hline $\mathrm{FC} / \mathrm{AP} / \mathrm{CHCl}_{3}$ & $84.37636 \pm 6.1306$ & $\mathrm{FH} / \mathrm{AP} / \mathrm{CHCl}_{3}$ & $0.87385 \pm 0.0672$ \\
$\mathrm{FC} / \mathrm{AP} / \mathrm{MeOH}$ & $\mathbf{0 . 0 4 4 3 3} \pm 0.0268$ & $\mathrm{FH} / \mathrm{AP} / \mathrm{MeOH}$ & $\mathbf{0 . 2 8 7 5 9} \pm 0.1564$ \\
$\mathrm{FC} /$ Root$/ \mathrm{PE}$ & $0.36386 \pm 0.2021$ & $\mathrm{FH} /$ Root $/ \mathrm{PE}$ & $8.59918 \pm 0.9382$ \\
$\mathrm{FC} /$ Root$/ \mathrm{CHCl}$ & $106.04545 \pm 12.8565$ & $\mathrm{FH} /$ Root $/ \mathrm{CHCl}$ & $25.33879 \pm 5.9761$ \\
$\mathrm{FC} / \mathrm{Root} / \mathrm{MeOH}$ & $4.45797 \pm 1.2348$ & $\mathrm{FH} /$ Root $/ \mathrm{MeOH}$ & $148.70455 \pm 17.9027$ \\
$\mathrm{FH} / \mathrm{AP} / \mathrm{PE}$ & $19.21394 \pm 0.0847$ & Donepezil & $0.00008 \pm 0.0000065$ \\
\hline
\end{tabular}

\section{DISCUSSION}

The methanol extracts of both species showed antioxidant activity in DPPH radical scavenging assay. Both extracts mostly contained different quinic acid and flavonoid derivatives which may be responsible for the activities. These phenolic compounds have antioxidant activities because of their reductant potentials of their phenolic hydroxyl groups. Since one-electron reduction potentials and reactivities of the phenolic 
radicals are lower than those of the reactive oxygen species (ROS), free radicals can be easily reduced by phenolic hydroxyl. Thus, phenolic compounds have radical scavenge activity on destructive radical species [34]. Position of the hydroxyl groups is a determinative factor of antioxidant capacities of the molecules as well as the second hydroxyl group in the ortho- position increases the antioxidant activity [35].

Oxidative damage is associated with aging and is widespread in the brain in Alzheimer disease. So, the extracts were studied for a correlation between antioxidant capacity and acetylcholinesterase inhibitory activities. The antioxidant methanol extract of the aerial parts of F. caspica showed the highest AChE inhibitory activity compared to other extracts.

In recent studies, F. halophila and F. elaeochytris methanol extracts displayed potent antioxidant capacities in comparison with apolar extracts $[36,37]$. Besides, in acetylcholinesterase inhibitory activity studies, the chloroform extracts of F. persica var. persica and F. halophila, as well as the hexane extract of $F$. elaeochytris, were assigned to be more active than methanolic extracts of the plants [36-38]. In addition, the acetylcholinesterase inhibitory activities of coumarin derivatives from F. gummosa and F. asafoetida species were determined, previously [30-41]. In the current study, the chloroform extracts of F. caspica and F. halophila that could be expected to contain some coumarin derivatives weren't found to be as active as methanol extracts of the plants compared to standard donepezil. The low activity of the chloroform extracts can be explained by the differences in the extraction procedures and the intensity of the active ingredients in the extracts.

Several studies in diabetes, demonstrated free radicals are increased by some reactions derived from the development of the disease and defense against radicals decreases [12, 13]. In addition, the activity of antioxidant enzymes in pancreatic homogenates from diabetic animals has been shown to decrease with oxidative stress [17, 42], however, further studies are needed to prove this claim for F. caspica and F. halophila extracts.

\section{CONCLUSION}

This is the first report to compare the phytochemical properties and activities of the roots and aerial parts of these two species. The methanol extracts from the aerial parts of F. caspica and F. halophila were found to show antioxidant and acetylcholinesterase inhibition activities. The activities complied with the total phenolic and flavonoid contents of the extracts and these results were associated with the content of secondary metabolites such as quinic acid and flavonoid derivatives of both species studied. In the present study, the higher AChE inhibitory activities of the methanol extracts gained from F. caspica and F. halophila can be explained by their higher antioxidant activities and phenolic compounds. However, high total phenolic content of the chloroform extract from the roots of F. caspica wasn't correlated with its antioxidant and acetylcholinesterase inhibitory activities.

\section{MATERIALS AND METHODS}

\subsection{Plant materials}

F. caspica was collected from Nallıhan-Davutoğlan Bird Paradise in June 2011 and F. halophila was collected from Şereflikoçhisar-Kaldırım Salina in June 2013, Ankara province Central Anatolia Region of Turkey. Voucher specimens were identified by Prof. Dr. Hayri Duman (Gazi University, Faculty of Science, Ankara, Turkey) and were deposited at the Herbarium of the Faculty of Pharmacy, Hacettepe University, Ankara, Turkey (HUEF 11003 and HUEF 13002).

\subsection{Extraction}

The aerial parts of $F$. caspica $(10 \mathrm{gr})$ were extracted with chloroform $(100 \mathrm{ml} \times 3)$ and methanol $(100 \mathrm{ml} \times$ 3), respectively, using a rotary extractor under $40{ }^{\circ} \mathrm{C}$ without vacuum. After the roots of $F$. caspica and $F$. halophila, as well as the aerial parts of $F$. halophila $(10 \mathrm{~g})$, were extracted with petroleum ether $(100 \mathrm{ml} \times 3)$, chloroform $(100 \mathrm{ml} \times 3)$ and methanol $(100 \mathrm{ml} \times 3)$, respectively. All of the obtained extracts were tested for antioxidant capacity, total phenolic content, acetylcholinesterase inhibitory activity and used for the analysis of the phenolic profile by liquid chromatography-mass spectrometry (LC-MS).

\subsection{Antioxidant capacity determined using the DPPH assay}

The free radical scavenging activity of the methanolic extract was evaluated by 1,1-diphenyl-2picrylhydrazyl (DPPH) according to the previously reported by Brand-Williams et al. [27] with slight modifications. After $50 \mu \mathrm{L}$ of $1 \mathrm{mM}$ DPPH solution was added to the $150 \mu \mathrm{L}$ of methanol extract prepared at 
the concentration of $200-25 \mu \mathrm{g} / \mathrm{ml}$ and shaken gently with a vortex mixer, the mixtures were incubated in dark at room temperature for $30 \mathrm{~min}$. The decrease in absorbance of mixtures was measured at $517 \mathrm{~nm}$ against blank using a UV spectrophotometer. Inhibition \% values of the extracts and reference compound were calculated using the formula below:

Inhibition \% $=\left[\left(\mathrm{A}_{\text {blank }}-\mathrm{A}_{\text {extract/reference }}\right) / \mathrm{A}_{\text {blank }}\right] \times 100$

Ablank expresses the absorbance of the mixture of all reagents without antioxidants. Quercetin was used as the reference compound and the calculated inhibition \% values of the extracts are given in Table 2.

\subsection{Determination of total phenolic content}

A slight modification of Folin-Ciocalteu assay described by Slinkard and Singleton [43] was used for the determination of phenolic content. According to method, $100 \mu \mathrm{L}$ of water diluted Folin-Ciocalteu reagent (1:10) was added to $20 \mu \mathrm{L}$ of methanol extract prepared at the concentration of $1000-500 \mu \mathrm{g} / \mathrm{ml}$. After the mixture was shaken gently, $80 \mu \mathrm{L}$ of $\mathrm{Na}_{2} \mathrm{CO}_{3}(7.5 \%)$ was added and the mixture was stored at room temperature for $2 \mathrm{~h}$. The absorbance was measured at $765 \mathrm{~nm}$ against blank and total phenolic content was determined using the standard calibration curve of gallic acid and expressed as gallic acid equivalents (Table 2).

\subsection{Determination of total flavonoid content}

For determination of total flavonoid content of the extracts, Aluminium Chloride Colorimetric Assay [44] was used $0.5 \mathrm{ml}$ solutions in different concentrations of the test materials were diluted with $1.5 \mathrm{ml}$ of $95 \%$ ethanol, $0.1 \mathrm{ml}$ of $10 \% \mathrm{AlCl}_{3}, 0.1 \mathrm{ml}$ of $1 \mathrm{M}$ Potassium Acetate $\left(\mathrm{CH}_{3} \mathrm{COOK}\right)$ and $2.8 \mathrm{ml}$ of distilled water. After incubation at room temperature for $30 \mathrm{~min}$, the absorbance was measured at $415 \mathrm{~nm}$ against the blank. The quantity of flavonoids was determined using the standard calibration curve of quercetin and results were expressed as mg quercetin equivalent per g extract (Table 2).

\subsection{LC-MS analysis of phenolic compounds}

Shimadzu 20A HPLC system, Absciex 3200 Q-Trap MS-MS detector and $250 \times 4.6 \mathrm{~mm}$ and analytic colon containing $5 \mu \mathrm{m}$ octadecyl silica were used for LC-MS/MS identification of phenolic compounds.

$5 \mu \mathrm{L}$ of methanol extract was injected to an octadecyl silica column and eluted with the mixture of mobile phase A:Acetonitrile:water:formic acid (10:89:1) and mobile phase B:Acetonitrile:water:formic acid (89:10:1) at a flow rate $0.5 \mathrm{ml} \mathrm{min}-1$. Column oven was set at $40{ }^{\circ} \mathrm{C}$ and the gradient began at $10 \%$ (B) and increased to $90 \%$ (B) during $40 \mathrm{~min}$. LC-ESI-MS / MS data were collected and processed with Analyst 1.6 software. The results are compared with the literature [45-51] and the possible definitions are given in Table 3.

\subsection{Acetylcholinesterase inhibitory activity}

Acetylcholinesterase inhibitor activity was measured by using Ellman's method [33]. In 96-well plates, phosphate buffer (500 mM, pH 7.4), acetylthiocholine iodide (5mM), 5,5'-dithiobis-2-nitrobenzoic acid (DTNB) $(0.125 \mathrm{mM})$ and $7 \mathrm{mg} / \mathrm{ml}-16 \mu \mathrm{g} / \mathrm{ml}$ concentrations of the extracts were pre-mixed and the enzymatic reaction was started with the addition of the acetylcholinesterase. Absorbance changes were measured at $412 \mathrm{~nm}$ by using a microplate reader. To evaluate the $\mathrm{IC}_{50}, \log$ concentration versus percentage of inhibition curve was plotted and analyzed using GraphPad Prism (Table 4).

Acknowledgements: This study was supported by Hacettepe University Scientific Research Projects Coordination Unit. Project Number: 014 D03 301 002-552.

The authors thank Dr. Barış Özüdoğru, Hacettepe University, Faculty of Science, Department of Botany, Ankara, Turkey for supporting the collecting plant material and Prof. Dr. Hayri Duman, Gazi University, Faculty of Science, Department of Botany, Ankara, Turkey, for authentification of the plant specimen.

Author contributions: Concept - Ç.K., Z.Ş.A.; Design - Ç.K., İ.B, İ.I.Ç., F.G., N.K., Z.Ş.A.; Supervision -Ç.K., Z.Ş.A.; Materials - Ç.K., İ.B., İİ.Ç., F.G.; Data Collection and/or Processing - Ç.K., İ.B, İ.I.Ç., F.G., N.K., Z.Ş.A.; Analysis and/or Interpretation - Ç.K., İ.B, İ.I.Ç., F.G., N.K., Z.Ş.A.; Literature Search - Ç.K., İ.B, F.G.; Writing - Ç.K., İ.B, İ.I.Ç., F.G., N.K., Z.Ş.A.; Critical Reviews - Ç.K., İ.B, İ.I.Ç., F.G., N.K., Z.Ş.A.

Conflict of interest statement: "The authors declared no conflict of interest" in the manuscript. 


\section{REFERENCES}

[1] Pimenov MG, Leonov MV. The Asian Umbelliferae Biodiversity Database (ASIUM) with particular reference to South-West Asian taxa. Turk J Bot. 2004; 28: 139-145.

[2] Duman H, Sağıroğlu M. A new species of Ferula (Apiaceae) from South Anatolia, Turkey. Bot J Linn Soc. 2005; 147(3): 357-361. [CrossRef]

[3] Peşmen H. Ferula L. in: Davis PH. (Ed). Flora of Turkey and the East Aegean Islands University Press, Edinburgh, 1972, pp. 440-453.

[4] Pimenov MG, Kljuykov EV. Ferula divaricata (Umbelliferae), a new species from Central Anatolia, Turkey. Phytotaxa. 2013; 99(1): 35-39. [CrossRef]

[5] Sagıroğlu M, Duman H. Ferula meroynii (Apiaceae), a distinct new species from north-east Anatolia, Turkey. Bot J Linn Soc. 2007; 153(3): 357-362. [CrossRef]

[6] Sağıroğlu M, Duman H. Ferula brevipedicellata and F. duranii (Apiaceae), two new species from Anatolia, Turkey. Ann Bot Fenn. 2010; 47(4): 293-300. [CrossRef]

[7] Sağıroğlu M. PhD Thesis. Revision of Turkısh Ferula L. (Umbelliferae). Deparment of Biology. Instute of Science and Tecnology, Gazi University, Ankara, Turkey, 2005.

[8] Sağıroğlu M, Duman H. Are Ferula tenuissima and F. amanicola distinct species or not. Bio Divers Conserv. 2014; 7(3): 74-77.

[9] Altundag E, Ozturk M. Ethnomedicinal studies on the plant resources of east Anatolia, Turkey. Procedia Soc Behav Sci 2011; 19: 756-777. [CrossRef]

[10] Al-Khalil S, Aqel M, Afifi F, Al-Eisawi D. Effects of an aqueous extract of Ferula ovina on rabbit and guinea pig smooth muscle. J Ethnopharmacol. 1990; 30(1): 35-42. [CrossRef]

[11] Aqel MB, Al-Khalil S, Afifi F. Effects of a Ferula sinaica root extract on the uterine smooth muscle of rat and guinea pig. J Ethnopharmacol. 1991; 31(3): 291-297. [CrossRef]

[12] Yusufoglu HS, Soliman GA, Abdel-Rahman RF, Abdel-Kader MS, Ganaie MA, Bedir E, Sura B, Ozturk B. Antihyperglycemic and antihyperlipidemic effects of Ferula duranii in experimental type 2 diabetic rats. Int J Pharm. 2015; 11(16): 532-541. [CrossRef]

[13] Yusufoglu HS, Soliman GA, Abdel-Rahman RF, Abdel-Kader MS, Genaie MA, Bedir E, Sura B, Ozturk B. Antioxidant and antihyperglycemic effects of Ferula drudeana and Ferula huber-morathii in experimental diabetic rats. Int J Pharm. 2015; 11(7): 738-748. [CrossRef]

[14] Zhang H, Lu J, Zhou L, Jiang L, Zhou M. Antioxidant and antitumor effects of Ferula sinkiangensis K.M.Shen. Int J Clin Exp Med. 2015; 8(11): 20845-20852.

[15] Gudarzi H, Salimi M, Irian S, Amanzadeh A, Mostafapour Kandelous H, Azadmanesh K, Salimi M. Ethanolic extract of Ferula gummosa is cytotoxic against cancer cells by inducing apoptosis and cell cycle arrest. Nat Prod Res. 2015; 29(6): 546-550. [CrossRef]

[16] Bashir S, Alam M, Ahmad B, Aman A. Antibacterial, anti-fungal and phytotoxic activities of Ferula narthex Boiss. Pak J Pharm Sci. 2014; 27(6): 1819-1825.

[17] Betteridge DJ. What is oxidative stress? Metabolism. 2000; 49(2): 3-8. [CrossRef]

[18] Somogyi A, Rosta K, Pusztai P, Tulassay Z, Nagy G. Antioxidant measurements. Physiol Meas. 2007; 28(4): R41-55. [CrossRef]

[19] Tönnies E, Trushina E. Oxidative stress, synaptic dysfunction, and Alzheimer's disease. J Alzheimers Dis. 2017; 57(4): 1105-1121. [CrossRef]

[20] Chen X, Guo C, Kong J. Oxidative stress in neurodegenerative diseases. Neural Regen Res. 2012; 7(5): 376-385. [CrossRef]

[21] Smith MA, Rottkamp CA, Nunomura A, Raina AK, Perry G. Oxidative stress in Alzheimer's disease. BBA - Mol Basis Dis. 2000; 1502(1): 139-144. [CrossRef]

[22] Bayer TA, Wirths O. Intracellular accumulation of amyloid-beta - A predictor for synaptic dysfunction and neuron loss in Alzheimer's disease. Front Aging Neurosci. 2010; 2: 8. [CrossRef] 
[23] Zhao Y, Zhao B. Oxidative stress and the pathogenesis of Alzheimer's disease. Oxid Med Cell Longev. 2013; 2013: 110. [CrossRef]

[24] Kim T-S, Pae C-U, Yoon S-J, Jang W-Y, Lee NJ, Kim J-J, Lee S-J, Lee C, Paik I-H, Lee C-U. Decreased plasma antioxidants in patients with Alzheimer's disease. Int J Geriatr Psychiatry. 2006; 21(4): 344-348. [CrossRef]

[25] Zaman Z, Roche S, Fielden P, Frost PG, Niriella DC, Cayley AC. Plasma concentrations of vitamins A and E and carotenoids in Alzheimer's disease. Age Ageing. 1992; 21(2): 91-94. [CrossRef]

[26] Huang D, Ou B, Prior RL. The chemistry behind antioxidant capacity assays. J Agric Food Chem. 2005; 53(6): 18411856. [CrossRef]

[27] Brand-Williams W, Cuvelier ME, Berset C. Use of a free radical method to evaluate antioxidant activity. LWT-Food Sci Technol. 1995; 28(1): 25-30. [CrossRef]

[28] Berker KI, Ozdemir Olgun FA, Ozyurt D, Demirata B, Apak R. Modified Folin-Ciocalteu antioxidant capacity assay for measuring lipophilic antioxidants. J Agric Food Chem. 2013; 61(20): 4783-4791. [CrossRef]

[29] Lhuillier A, Fabre N, Cheble E, Oueida F, Maurel S, Valentin A, Fouraste I, Moulis C. Daucane sesquiterpenes from Ferula hermonis. J Nat Prod. 2005; 68(3): 468-471. [CrossRef]

[30] Alkhatib R, Hennebelle T, Joha S, Roumy V, Guzel Y, Biabiany M, Idziorek T, Preudhomme C, Quesnel B, Sahpaz S, Bailleul F. Humulane and germacrane sesquiterpenes from Ferula lycia. J Nat Prod. 2010; 73(4): 780-783. [CrossRef]

[31] Kurimoto S-i, Suzuki K, Okasaka M, Kashiwada Y, Kodzhimatov OK, Takaishi Y. New sesquiterpene lactone glucosides from the roots of Ferula varia. Phytochem Lett. 2012; 5(4): 729-733. [CrossRef]

[32] Li G, Li X, Cao L, Zhang L, Shen L, Zhu J, Wang J, Si J. Sesquiterpene coumarins from seeds of Ferula sinkiangensis. Fitoterapia. 2015; 103: 222-226. [CrossRef]

[33] Ellman GL, Courtney KD, Andres V, Featherstone RM. A new and rapid colorimetric determination of acetylcholinesterase activity. Biochem Pharmacol. 1961; 7: 88-95. [CrossRef]

[34] Grace SC. Phenolics as Antioxidants. in: Smirnoff, N. (Ed). Antioxidants and Reactive Oxygen Species in Plants. Blackwell Publishing Ltd, Oxford, 2005, pp. 141-168.

[35] Rice-Evans CA, Miller NJ, Paganga G. Structure-antioxidant activity relationships of flavonoids and phenolic acids. Free Radic Biol Med. 1996; 20(7): 933-956. [CrossRef]

[36] Deveci E, Tel-Cayan G, Duru ME. Phenolic profile, antioxidant, anticholinesterase, and anti-tyrosinase activities of the various extracts of Ferula elaeochytris and Sideritis stricta. Int J Food Prop. 2018; 21(1): 771-783. [CrossRef]

[37] Zengin G, Uysal A, Diuzheva A, Gunes E, Jekő J, Cziáky Z, Picot-Allain CMN, Mahomoodally MF. Characterization of phytochemical components of Ferula halophila extracts using HPLC-MS/MS and their pharmacological potentials: A multi-functional insight. J Pharm Biomed Anal. 2018; 160: 374-382. [CrossRef]

[38] Maritim AC, Sanders RA, Watkins JB 3rd. Diabetes, oxidative stress, and antioxidants: A review. J Biochem Mol Toxicol. 2003; 17(1): 24-38. [CrossRef]

[39] Adhami H-R, Fitz V, Lubich A, Kaehlig H, Zehl M, Krenn L. Acetylcholinesterase inhibitors from galbanum, the oleo gum-resin of Ferula gummosa Boiss. Phytochem Lett. 2014; 10: 1xxxii-lxxxvii. [CrossRef]

[40] Adhami HR, Scherer U, Kaehlig H, Hettich T, Schlotterbeck G, Reich E, Krenn L. Combination of bioautography with HPTLC-MS/NMR: A fast identification of acetylcholinesterase inhibitors from galbanum(dagger). Phytochem Anal. 2013; 24(4): 395-400. [CrossRef]

[41] Kumar P, Singh VK, Singh DK. Kinetics of enzyme inhibition by active molluscicidal agents ferulic acid, umbelliferone, eugenol and limonene in the nervous tissue of snail Lymnaea acuminata. Phytother Res. 2009; 23(2): 172-177. [CrossRef]

[42] Shekarchi M, Hajimehdipoor H, Naghibi F, Ara L, Moazzeni Zehan H. Investigating acetylcholinesterase inhibitory effects of some Ferula species. J Med Plants. 2013; 2(46): 106-112.

[43] Slinkard K, Singleton VL. Total phenol analysis: automation and comparison with manual methods. Am J Enol Vitic. 1977; 28: 49-55.

[44] Chang CC, Yang MH, Wen HM, Chern JC. Estimation of total flavonoid content in propolis by two complementary colorimetric methods. J Food Drug Anal. 2002; 10(3): 178-182.

[45] Abu-Reidah IM, Ali-Shtayeh MS, Jamous RM, Arráez-Román D, Segura-Carretero A. HPLC-DAD-ESI-MS/MS screening of bioactive components from Rhus coriaria L. (Sumac) fruits. Food Chem. 2015; 166: 179-191. [CrossRef] 
[46] Abu-Reidah IM, Contreras MM, Arraez-Roman D, Segura-Carretero A, Fernandez-Gutierrez A. Reversed-phase ultra-high-performance liquid chromatography coupled to electrospray ionization-quadrupole-time-of-flight mass spectrometry as a powerful tool for metabolic profiling of vegetables: Lactuca sativa as an example of its application. J Chromatogr A. 2013; 1313: 212-227. [CrossRef]

[47] Barros L, Dueñas M, Ferreira ICFR, Maria Carvalho A, Santos-Buelga C. Use of HPLC-DAD-ESI/MS to profile phenolic compounds in edible wild greens from Portugal. Food Chem. 2011; 127(1): 169-173. [CrossRef]

[48] Clifford MN, Knight S, Kuhnert N. Discriminating between the six isomers of dicaffeoylquinic acid by LC-MS(n). J Agric Food Chem. 2005; 53(10): 3821-3832. [CrossRef]

[49] Dias MI, Barros L, Duenas M, Alves RC, Oliveira MB, Santos-Buelga C, Ferreira IC. Nutritional and antioxidant contributions of Laurus nobilis L. leaves: would be more suitable a wild or a cultivated sample? Food Chem. 2014; 156: 339-346. [CrossRef]

[50] Ferreres F, Pereira DM, Valentao P, Andrade PB. First report of non-coloured flavonoids in Echium plantagineum bee pollen: differentiation of isomers by liquid chromatography/ion trap mass spectrometry. Rapid Commun Mass Spectrom. 2010; 24(6): 801-806. [CrossRef]

[51] Hvattum E, Ekeberg D. Study of the collision-induced radical cleavage of flavonoid glycosides using negative electrospray ionization tandem quadrupole mass spectrometry. J Mass Spectrom. 2003; 38(1): 43-49. [CrossRef]

This is an open access article which is publicly available on our journal's website under Institutional Repository at http://dspace.marmara.edu.tr. 